\title{
PIKETTY, EKONOMIJA I SOCIOLOGIJA: ZNANSTVENA I POLITIČKA AGENDA O NEJEDNAKOSTI
}

\section{Marko Grdešić}

Fakultet političkih znanosti

DOI: 10.20901/an.12.08

Sveučilište u Zagrebu

Pregledni rad

E-mail:mgrdesic@fpzg.hr

Primljeno: ožujak 2016.

\begin{abstract}
Sažetak Ovaj rad kritički razmatra rad Thomasa Pikettya o nejednakosti, s posebnim fokusom na recepciji njegovih ideja u društvenim znanostima. Najprije se kvantitativnom analizom tekstova koji citiraju Pikettyjeve najvažnije radove istražuje recepcija Pikettyja u akademskim raspravama. Zatim se detaljnije razmatraju tipovi kritika koje dolaze iz ekonomije i sociologije, dviju često suprotstavljenih disciplina koje su se najviše posvetile raspravama o Pikettyju. Ovaj rad nadopunjuje postojeće kritike dodatnim prijedlozima koji su relevantni za znanstveno bavljenje nejednakošću i za proces zamišljanja reformi koje bi se s nejednakošću mogle nositi.
\end{abstract}

Ključne riječi Piketty, ekonomija, sociologija, nejednakost

Uvod

U ovom se tekstu kritički analizira rad Thomasa Pikettyja, ponajprije u svjetlu njegove recepcije $\mathrm{u}$ društvenim znanostima. Piketty je uspio uhvatiti duh vremena te zanimanje šire javnosti za nejednakost pretvoriti u velik komercijalni uspjeh, rijetko viđen kod akademskih autora. Nakon osvajanja ljestvica čitanosti New York Timesa i Amazona, Pikettyjeva je knjiga Kapital u 21. stolje- ću konsolidirala temu nejednakosti kao jednu od najvažnijih političkih i ekonomskih tema 21. stoljeća. Kako vrednovati Pikettyjev rad? Kakva je bila recepcija njegovog rada u društvenim znanostima? Da li sociologija i ekonomija - često suprotstavljene discipline drugačije gledaju na Pikettyja? Kako bi se njegov pristup mogao dalje razvijati? Kako bi se njegove policy preporuke za smanjivanje nejednakosti mogle nadopuniti? 
Ovaj rad pokušava dati odgovore na ta pitanja. Rad je organiziran na sljedeći način. Prvi dio daje kratki sažetak osnovnih Pikettyjevih nalaza i teza, fokusirajući se uglavnom na Kapital, kao njegov glavni rad. Drugi dio predstavlja rezultate kvantitativne analize tekstova koji citiraju Pikettyjeve najvažnije radove. Za potrebe ove analize, sakupljeno je oko 250 radova koji citiraju Pikettyja u raznim znanstvenim publikacijama. Treći i četvrti dio detaljnije razmatraju kritike koje Pikettyju upućuju ekonomija i sociologija. I na kraju, peti dio predstavlja nadopunu postojeće sociološke i ekonomske kritike. Ovaj posljednji dio rada daje neke sugestije o tome kako bi se Pikettyjeva istraživačka i reformatorska agenda mogla dalje razvijati, nakon što je Piketty svojom spektakularnom popularnošću afirmirao nejednakost kao jednu od ključnih tema našeg vremena.

Glavni se zaključci ovog rada mogu sažeti na sljedeći način. Recepcija Pikettyja u društvenim znanostima relativno je uravnotežena. Sličan postotak radova čita njegov doprinos u pozitivnom kao i u negativnom svijetlu. Recepcija je Pikettyjevog rada u sociologiji bila nešto pozitivnija nego u ekonomiji. Što se tiče konkretnih kritika, ekonomisti češće kritiziraju definicije koje Piketty upotrebljava te osporavaju neke mjere koje on konstruira. S druge strane, sociolozi češće kritiziraju način na koji Piketty definira klase i nedostatak sistematičnog teoretiziranja uloge političkog djelovanja i društvenih pokreta. Ova je posljednja kritika posebno relevantna jer upućuje ne samo na relativno ateorijske osnove Pikettyjevog pothvata već i na slabosti u potencijalnoj provedbi njegove glavne policy preporuke, globalnog progresivnog poreza na bogatstvo. Zato posljednji dio ovog rada skicira određe- ne alternativne politike koje bi se mogle zamisliti jednom kada se izađe iz tehnokratskog okvira unutar kojeg razmišlja Piketty.

\section{Prikaz Pikettyjevih ideja}

Glavno pitanje koje si Piketty postavlje u Kapitalu jest vodi li na dugi rok kapitalizam do više ili do manje nejednakosti. Crni scenarij - da kapitalizam dovodi do sve veće koncentracije bogatstva - ponudio je Karl Marx (Piketty 2014: 9). Alternativnu i mnogo optimističniju priču ponudio je Simon Kuznets, po kojem nejednakost raste u inicijalnoj fazi ekonomskog rasta, a počinje opadati kako zemlje konvergiraju ka modernom tipu industrijalizirane privrede (Piketty, 2014: 22-23).

$\mathrm{Da}$ bi odgovorio na ovo pitanje, $\mathrm{Pi}$ ketty je sakupio podatke o poreznim prijavama za nekoliko zemalja, od kojih se najduže vremenske serije mogu konstruirati za Francusku, Veliku Britaniju i SAD. Na temelju tih podataka - od kojih neki sežu do kraja 18. stoljeća i početka 19. stoljeća - Piketty je u stanju dati nove uvide $\mathrm{u}$ dugoročne distribucijske trendove. Podaci koje je Piketty prikupio u suradnji s kolegama Emmanuelom Saezom i Anthonyjem Atkinsonom glavna su prednost ove knjige. Dosad nije napisana knjiga o nejednakosti koja bi raspolagala podacima usporedive kvalitete. Treba pri tome napomenuti da je čitava baza podataka "World Top Incomes Database" javno dostupna. ${ }^{1}$

Za Pikettyja je nejednakost važna jer stabilnost kapitalizma ovisi o tome da se društvena elita legitimira meritokratski. Bogatstvo mora u neku ruku biti zasluženo, tj. mora biti rezultat produktivnih

1 Vidi: http://www.wid.world/. Pristupljeno 4. travnja 2016. 
poduzetničkih aktivnosti. Međutim, ukoliko je bogastvo uglavnom zasluga prethodne akumulacije na temelju koje najbogatiji pojedinci mogu uživati rentijerski stil života, legitimnost kapitalizma biva duboko uzdrmana. Upravo na toj smjer nas navodi Pikettyjev glavni zaključak, njegovo "središnje proturječje kapitalizma" (Piketty, 2014: 677): stopa povrata na kapital $r$ je na dugi rok veća od stope ekonomskog rasta $g$, što vodi do stvaranja velikih dinastijskih bogatstava. Po njegovim je izračunima dugoročni $r$ između 4 i 5 posto, a $g$ između $1 \mathrm{i}$ 1.5 posto (Piketty, 2014: 110-112, 400406). Odnos $r>g$ bi zbog toga mogao pretvoriti društvo 21. stoljeća u rentijersko društvo tj. u patrimonijalni kapitalizam u kojem bi odnos naslijeđenog naspram zasluženog bogatstva stalno rastao, destabilizirajući time i sam kapitalistički poredak.

Takvo je rentijersko društvo već postojalo u razdoblju prije Prvog svjetskog rata, Velike depresije i Drugog svjetskog rata. Međutim, ovi su šokovi uvelike komprimirali distribuciju nejednakosti koja se do tada relativno spontano razvijala. Najveća bogastva uklonjena su kombinacijom fizičkog uništenja, inflacije i konfiskatornog oporezivanja. Međutim, ti su događaji iznimka dok se na dugi rok ponovno nameće tendencija $r>g$. U suvremenom kontekstu usporenog demografskog rasta i usporenog porasta produktivnosti (Piketty, 2014: 99, 111-112), ne treba očekivati da će se stope ekonomskog rasta podići dovoljno visoko da neutraliziraju ovu tendenciju. Piketty iz toga ne izvodi radikalne zaključke, već predlaže progresivno oporezivanje. Premda Piketty spominje Marxa i "kapitalistička proturječja", te u naslovu aludira na Marxov Kapital, njegova knjiga i metodološki i politički ostaje na terenu umjerene kritike. Za sebe tvrdi da je doživotno "cijepljen" protiv lijenog ljevičarskog antikapitalističkog diskursa (Piketty, 2014: 42). Vjerojatno je takvo retoričko pozicioniranje izvan "ekstrema", bilo lijevih bilo liberalnih, pomoglo Pikettyjevom Kapitalu da postigne veliki komercijalni uspjeh.

Prema Pikettyju, rentijersko je društvo zapravo normalna tendencija kapitalizma, a razdoblje sredine dvadesetog stoljeća - iznimka. Da bi nadopunio kvantitativne podatke, Piketty se često koristi primjerima iz beletristike i popularne kulture. Najčešće se oslanja na romane Jane Austen i Honoréa de Balzaca, u kojima se mogu pronaći opisi rentijerskog društva te brojni likovi koji dobro shvaćaju da je do bogatstva mnogo lakše doći brakom ili naslijeđivanjem nego radom. U devetnaeststoljetnom je društvu povrat na kapital toliko stabilan da likovi iz romana Jane Austen bez problema mogu izračunati koliko bi nečiji imetak trebao biti velik da bi omogućio rentu za lagodan život (Piketty, 2014: 233-234). Balzacovi likovi, najupečatljivije Vautrin iz romana Otac Goriot, pak vrlo uvjerljivo argumentiraju da se napornim radom nikad ne može doći do bogatstva koje bi bilo potrebno za ugodan život u krugu pariške elite (Piketty, 2014: 268-270).

Ovaj fokus na bogatstvo pomalo je neobičan za ekonomiste. Njegova definicija kapitala odudara od uobičajene. Naime, za Pikettyja kapital ne uključuje samo strojeve i ostali kapital koji izravno sudjeluje u proizvodnji, već i bogatstvo. To uključuje sve ono nad čime pojedinci drže vlasnička prava (kuće, automobile i umjetničke kolekcije), te sve ono što posjeduju na svojim računima, umanjeno za moguća dugovanja (Piketty, 2014: 5658). Ovaj pristup odudara od konvencija u ekonomiji, ali omogućuje Pikettyju da na jednostavan način kvantificira odnos prošlosti (akumulirano bogatstvo) i sa- 
dašnjosti (nacionalni dohodak). Na temelju podataka pokazuje da je ovaj odnos obično oko 6 naprema 1 (Piketty, 2014: 61-62). Zato Piketty može reći da "prošlost proždire budućnost" (Piketty, 2014: 677).

Pikettyjevi su podaci raznovrsni i bogati. Veći dio knjige fokusira se na najbogatiji percentil imovinske distribucije, tj. na top 1 posto. $^{2}$ Podaci dobiveni iz poreznih prijava omogućuju potpuniji uvid u dio imovinske distribucije koji obično ne biva zahvaćen metodama kao što su ankete. Međutim, porezne agencije u većini zapadnih zemalja uživaju dostatan ugled pa čak i bogati građani uglavnom surađuju pri predaji porezne prijave. U Francuskoj su podaci najbolji zbog vrlo modernog sustava prikupljanja poreznih podataka koji je uspostavljen još za vrijeme Francuske revolucije. Osnovni trend koji vrijedi za većinu zapadnih zemalja, ali i za mnoge zemlje u razvoju (Piketty 2014: 371), jest porast nejednakosti u posljednih tridesetak godina. Razlike između zemalja postoje i dalje te je porast udjela ukupnog bogatstva koji pripada najbogatijem postotku najveći u anglosaksonskim zemljama, pogotovo u SAD (Piketty, 2014: 358-359, 362-263). Osim podataka o nejednakosti, Piketty iznosi niz zanimljivih podataka o kretanju javnog (državnog) kapitala naspram privatnom kapitalu, o kretanju javnog duga, te o kretanju poreznih stopa.

Upravo oporezivanje vidi kao glavno rješenje za postojeći porast nejednakosti

2 Pri tome volje napomenuti da je sama distribucija fraktalnog karaktera pa je unutar top 1 posto top 0.1 posto mnogo bogatiji od ostatka tog percentila, a unutar top 0.1 su pak mnogo bogatiji top 0.01 posto i tako dalje sve do nasljednice L'Oréala Liliane Bettencourt, omiljenog Pikettyjevog primjera (Piketty, 2014: 508, 614). i kapitalizmu inherentnu tendenciju $r>g$. Pred kraj knjige Piketty izlaže svoju glavnu policy preporuku: progresivno oporezivanje. Po mogućnosti, taj bi se porez uveo na globalnoj razini (Piketty, 2014: 602-605), ali moglo bi se započeti i na europskoj razini (Piketty, 2014: 619623). Piketty predlaže porezne stope od 0.1 posto za bogastva do 200 tisuća eura, 0.5 posto za bogatstva do 1 milijun eura, 2 posto za bogatstva do 5 milijuna i 5 posto za najveća bogatstva (Piketty, 2014: 621-622). Razmatra i druge scenarije kojima se može smanjiti nejednakost, poput inflacije (Piketty, 2014: 151, 524). Međutim, inflacija je proces kojim je teško upravljati, a upitno je da li pogađa najveća bogatstva. Osim toga, progresivno oporezivanje imalo bi tu prednost da bi se moralo provesti zakonima pa bi imalo i veću demokratsku legitimaciju. Zato Piketty svoju knjigu završava apelom da se razmotri porezna reforma na globalnoj razini.

\section{Kvantitativna analiza citata}

Kakav je bio odjek Pikettyjeva rada u društvenim znanostima? Tko ga citira? Kako ga se citira? Da bi se dali odgovori na ova pitanja, prikupljeni su podaci o radovima koji citiraju Pikettyjeve najvažnije radove. U široj je javnosti najzapaženiji Pikettyjev rad zasigurno njegov Kapital. Međutim, Piketty je u akademskim krugovima postao poznat starijim člankom napisanim u koautorstvu $\mathrm{s}$ Emmanuelom Saezom. Riječ je o članku "Dohodovna nejednakost u SAD, 19131998." koji je objavljen u Quarterly Journal of Economics (Piketty i Saez, 2003). Ovaj rad predstavlja dio prikupljenih podataka o nejednakosti, uglavnom je deskriptivne prirode i ne sadrži širu argumentaciju koju je Piketty dodao u $\mathrm{Ka}$ pitalu. "Dohodovna nejednakost" i $\mathrm{Ka}$ - 
pital su njegovi najcitiraniji radovi. Zbog popularnosti "Dohodovne nejednakosti" bilo je potrebno prikupiti informacije o radovima koji citiraju i taj tekst, a ne samo o radovima koji citiraju Kapital. Kombiniranjem Kapitala i "Dohodovne nejednakosti” može se steći uvid u različite Pikettyjeve osobe: (1) pesimistični Piketty iz Kapitala $(r>g)$ i (2) uglavnom neutralni sakupljač podataka iz "Dohodovne nejednakosti."

Kako su podaci prikupljeni? Najprije se pretragom na bazi Google Scholar došlo do popisa radova koji citiraju $\mathrm{Ka}$ pital. Prvih je 100 radova uključeno u analizu. Radovi su rangirani prema tome koliko često su sami citirani. Ista je procedura ponovljena za "Dohodovnu nejednakost." Zatim, napravljena je pretraga za riječ "Piketty" u nekoliko najvažnijih baza za društvene znanosti: EconLit za ekonomiju, SocINDEX za sociologiju i Worldwide Political Science Abstracts za političku znanost. Uključeni su radovi koji su citirani barem jednom. Radovi koje je napisao Piketty ili jedan od njegovih glavnih koautora (Atkinson i Saez) bili su isključeni. Također su bili isključeni neakademski radovi kao što su tekstovi o Pikettyju objavljeni u New York Timesu, The Economistu ili na blogovima. Sve u svemu, to je rezultiralo bazom od 255 radova.

Kakvi se uvidi mogu dobiti iz ovih podataka? Sljedeće su kategorije kodirane za svaku jedinicu: (1) da li je Pikettyjev rad evaluiran kao pozitivan? (2) da li je Pikettyjev rad evaluiran kao negativan? (3) da li je citat Pikettyja u osnovi kurtoazan, tako da se umjesto njega moglo citirati neki drugi rad o nejednakosti? (4) da li se Pikettyja citira kao izvor podataka, tj. da bi se potkrijepila empirijska tvrdnja poput: "U posljednjih je nekoliko desetljeća bogatstvo najbogatijih 1 posto naglo poraslo." Također je praćeno koliko svaki rad u bazi ima citata. Ova je informacija uzeta iz baze Google Scholar. Dalje, za svaki je tekst unesena i informacija o tome koliko se puta spominje Pikettyjevo ime. Ovo je uzeto kao indikator detaljnosti kojom se tekst bavi Pikettyjem. Svaka je jedinica kodirana dva puta, a provjere pouzdanosti kodiranja bile su relativno visoke. Za Cohenovu Kappu i Krippendorffovu Alphu dobivene su vrijednosti od oko 0.93.

Što kažu podaci? Tablica 1 prikazuje deskriptivnu statistiku. Najprije treba reći da je postotak radova koji predstavljaju pozitivno čitanje Pikettyja otprilike isti kao postotak radova koji predstavljaju negativno čitanje Pikettyja (oko 20 posto). Pri tome valja napomenuti da postoji razlika između recepcije Kapitala i "Dohodovne nejednakosti." U usporedbi s "Dohodovnom nejednakošću”, Kapital ima viši udio i negativnih i pozitivnih evaluacija. Prema tome, Kapital izaziva puno oštrije podjele: 29 posto pozitivnih evaluacija naspram 37 posto negativnih za Kapital te 10 posto pozitivnih i 5 posto negativnih za "Dohodovnu nejednakost.” Drugim riječima, percepcija Kapitala je blago negativna, dok je percepcija "Dohodovne nejednakosti" blago pozitivna, premda taj tekst nije tako kontroverzan. Na primjer, kada konzervativni ekonomist Gregory Mankiw komentira "Dohodovnu nejednakost" onda konstatira da taj članak predstavlja "najbolje podatke koje imamo o gornjem dijelu dohodovne distribucije" (Mankiw 2013: 22). Međutim, kada piše o Kapitalu, Mankiw signalilzira svoje neslaganje s Pikettyjem već u naslovu svog teksta " $D a$, $r>g$. Pa što onda?" (Mankiw, 2015).

Neki autori istovremeno i hvale i kritiziraju. Od 39 radova koji pozitivno čitaju Kapital njih je 29 istovremeno tu knjigu čitalo na negativni način. Pozitiv- 
Tablica 1. Deskriptivna statistika

\begin{tabular}{|c|c|c|c|c|c|c|}
\hline & $\begin{array}{l}\text { Svi uključeni } \\
\text { radovi, } \\
\mathrm{N}=255\end{array}$ & $\begin{array}{c}\text { Radovi koji } \\
\text { citiraju } \\
\text { Kapital, } \\
\mathrm{N}=136\end{array}$ & $\begin{array}{l}\text { Radovi koji } \\
\text { citiraju } \\
\text { “Dohodovnu } \\
\text { nejed- } \\
\text { nakost”, } \\
\text { N=141 }\end{array}$ & $\begin{array}{l}\text { Radovi u } \\
\text { bazi EconLit } \\
\text { (ekonomija), } \\
\quad \mathrm{N}=52\end{array}$ & $\begin{array}{c}\text { Radovi u } \\
\text { bazi } \\
\text { SocINDEX } \\
\text { (sociologija), } \\
\mathrm{N}=19\end{array}$ & $\begin{array}{c}\text { Radovi u } \\
\text { bazi } \\
W W P S A \\
\text { (politička } \\
\text { znanost), } \\
\mathrm{N}=16\end{array}$ \\
\hline $\begin{array}{l}\text { Pozitivna } \\
\text { evaluacija } \\
\text { Pikettyja }\end{array}$ & $\begin{array}{c}47 \text { od } 255 \\
(18.4 \text { posto })\end{array}$ & $\begin{array}{c}39 \text { od } 136 \\
(28.7 \text { posto })\end{array}$ & $\begin{array}{l}14 \text { od } 141 \\
(9.9 \text { posto) }\end{array}$ & $\begin{array}{c}20 \text { od } 52 \\
(38.5 \text { posto })\end{array}$ & $\begin{array}{c}16 \text { od } 19 \\
(84.2 \text { posto })\end{array}$ & $\begin{array}{c}7 \text { od } 16 \\
(43.8 \text { posto })\end{array}$ \\
\hline $\begin{array}{c}\text { Negativna } \\
\text { evaluacija } \\
\text { Pikettyja }\end{array}$ & $\begin{array}{c}52 \text { od } 255 \\
(20.4 \text { posto })\end{array}$ & $\begin{array}{c}50 \text { od } 136 \\
(36.8 \text { posto })\end{array}$ & $\begin{array}{c}7 \text { od } 141 \\
(5.0 \text { posto) }\end{array}$ & $\begin{array}{c}27 \text { od } 52 \\
(51.9 \text { posto })\end{array}$ & $\begin{array}{c}15 \text { od } 19 \\
(79.0 \text { posto })\end{array}$ & $\begin{array}{c}9 \text { od } 16 \\
(56.3 \text { posto })\end{array}$ \\
\hline $\begin{array}{l}\text { Kurtoazni } \\
\text { citat }\end{array}$ & $\begin{array}{c}67 \text { od } 255 \\
(26.3 \text { posto })\end{array}$ & $\begin{array}{c}41 \text { od } 136 \\
(30.2 \text { posto })\end{array}$ & $\begin{array}{c}30 \text { od } 141 \\
(21.3 \text { posto })\end{array}$ & $\begin{array}{c}2 \text { od } 52 \\
(3.9 \text { posto })\end{array}$ & $\begin{array}{c}1 \text { od } 19 \\
(5.3 \text { posto })\end{array}$ & $\begin{array}{c}1 \text { od } 16 \\
(6.3 \text { posto })\end{array}$ \\
\hline $\begin{array}{c}\text { Piketty } \\
\text { kao podaci }\end{array}$ & $\begin{array}{l}116 \text { od } 255 \\
(45.5 \text { posto })\end{array}$ & $\begin{array}{c}32 \text { od } 136 \\
(23.5 \text { posto })\end{array}$ & $\begin{array}{c}95 \text { od } 141 \\
(67.4 \text { posto })\end{array}$ & $\begin{array}{c}10 \text { od } 52 \\
(19.2 \text { posto })\end{array}$ & $\begin{array}{c}1 \text { od } 19 \\
(5.3 \text { posto })\end{array}$ & $\begin{array}{c}6 \text { od } 16 \\
(37.5 \text { posto })\end{array}$ \\
\hline $\begin{array}{c}\text { Spomeni } \\
\text { Pikettyjeva } \\
\text { imena }\end{array}$ & $\begin{array}{c}\text { Prosjek }= \\
17.3 \\
\text { Medijan }=5\end{array}$ & $\begin{array}{c}\text { Prosjek }= \\
25.6 \\
\text { Medijan }=9\end{array}$ & $\begin{array}{c}\text { Prosjek }= \\
13.4 \\
\text { Medijan }=5\end{array}$ & $\begin{array}{c}\text { Prosjek }= \\
41.7 \\
\text { Medijan }=22\end{array}$ & $\begin{array}{c}\text { Prosjek }= \\
47.5 \\
\text { Medijan }=41\end{array}$ & $\begin{array}{c}\text { Prosjek }= \\
45.8 \\
\text { Medijan }=39\end{array}$ \\
\hline Broj citata & $\begin{array}{c}\text { Prosjek = } \\
155.1 \\
\text { Medijan = } 14\end{array}$ & $\begin{array}{c}\text { Prosjek }= \\
17.5 \\
\text { Medijan }=6\end{array}$ & $\begin{array}{c}\text { Prosjek }= \\
260.7 \\
\text { Medijan = } \\
112\end{array}$ & $\begin{array}{c}\text { Prosjek }= \\
33.5 \\
\text { Medijan }=7\end{array}$ & $\begin{array}{c}\text { Prosjek }= \\
20.8 \\
\text { Medijan }=3\end{array}$ & $\begin{array}{c}\text { Prosjek }= \\
18.8 \\
\text { Medijan }=5\end{array}$ \\
\hline
\end{tabular}

na i negativna evaluacija može biti sadržana u istom radu. Dobar je primjer članak Deirdre McCloskey (2014: 75): "Ništa što ću reći - a reći ću neke teške stvari, jer su istinite i važne - ne pobija Pikettyjev integritet i njegov znanstveni napor." To sugerira kako je mnogo autora ozbiljno razmotrilo Pikettyjev rad, pažljivo važući njegove prednosti i mane. Međutim, također postoji mnogo usputnih čitaoca Pikettyja. Na primjer, oko 30 posto je radova citiralo Kapital na kurtoazni način, tj. tako da se citat Pikettyja lako mogao zamijeniti nekim drugim radom koji se bavi sličnim temama. "Dohodovna nejednakost" se pak najčešće citira kao izvor podataka: oko dvije trećine radova koji citiraju taj tekst koristi Pikettyja na taj način.

Razlike između disciplina također su zanimljive. Od 52 rada koji su prikupljeni u ekonomskoj bazi EconLit, ukupno je
20 imalo pozitivnu evaluaciju Pikettyja, dok je 27 imalo negativnu. To sugerira blagu negativnu recepciju Pikettyjeva rada unutar ekonomske znanosti. To je tako uglavnom zbog Kapitala, koji je izazvao snažnije reakcije od "Dohodovne nejednakosti." Broj radova koji je prikupljen u sociološkoj bazi SocINDEX je relativno malen (19), pa s interpretacijom treba biti pažljiv. U toj grupi, čini se da Pikettyjev rad izaziva nešto snažnije reakcije: oko 84 posto je imalo pozitivno, a 80 posto negativnu evaluaciju njegova rada. Ponovno, to je uglavnom tako zbog Kapitala. Drugim riječima, i ekonomija i sociologija su o Pikettyju rekle i neke pozitivne i neke negativne stvari. Čini se da sociologija Pikettyju daje nešto više podrške. Međutim, treba ponovno reći da nisu svi ekonomisti neprijateljski nastrojeni spram Pikettyja. Neka su mu ugledna imena stala u obranu. 
Primjerice, Branko Milanović je u svojoj recenziji Kapitala napisao da "smo u prisustvu prijelomne knjige ekonomskog mišljenja" (Milanović, 2014: 519). Kada je riječ o politološkoj bazi WWPSA, broj radova je još niži pa se nikakvi zaključci ne mogu ponuditi.

Razlike među disciplinama mogu se promatrati i u multivarijantnom kontekstu. Tablica 2 prikazuje rezultate tri mo-

Tablica 2. Multivarijantni modeli

\begin{tabular}{|c|c|c|c|}
\hline & (1) & (2) & (3) \\
\hline & Logistička regresija & $\begin{array}{l}\text { Logistička } \\
\text { regresija }\end{array}$ & Linearna regresija \\
\hline & $\begin{array}{c}\text { Zavisna varijabla: } \\
\text { Pozitivna } \\
\text { evaluacija Pikettyja }\end{array}$ & $\begin{array}{l}\text { Zavisna varijabla: } \\
\text { Negativna } \\
\text { evaluacija Pikettyja }\end{array}$ & $\begin{array}{c}\text { Zavisna varijabla: } \\
\text { Spomeni Pikettyjeva } \\
\text { imena (log) }\end{array}$ \\
\hline Pozitivna evaluacija & & $\begin{array}{l}-0.238 \\
(0.718)\end{array}$ & $\begin{array}{c}0.886^{* * *} \\
(0.156)\end{array}$ \\
\hline Negativna evaluacija & $\begin{array}{l}-0.372 \\
(0.711)\end{array}$ & & $\begin{array}{c}0.885^{\star * \star} \\
(0.168)\end{array}$ \\
\hline Rad u bazi Google Scholar & $\begin{array}{l}1.594^{*} \\
(0.788)\end{array}$ & $\begin{array}{c}0.674 \\
(0.831) \\
\end{array}$ & $\begin{array}{l}-0.275 \\
(0.189) \\
\end{array}$ \\
\hline $\begin{array}{l}\text { Rad u bazi EconLit } \\
\text { (ekonomija) }\end{array}$ & $\begin{array}{c}0.658 \\
(0.719)\end{array}$ & $\begin{array}{l}1.837^{*} \\
(0.821)\end{array}$ & $\begin{array}{c}0.697^{* * *} \\
(0.176)\end{array}$ \\
\hline $\begin{array}{c}\text { Rad u bazi SocINDEX } \\
\text { (sociologija) }\end{array}$ & $\begin{array}{l}3.867^{* * *} \\
(1.071)\end{array}$ & $\begin{array}{c}2.390 \\
(1.229)\end{array}$ & $\begin{array}{c}0.049 \\
(0.253)\end{array}$ \\
\hline $\begin{array}{l}\text { Rad u bazi WWPSA } \\
\text { (politička znanost) }\end{array}$ & $\begin{array}{l}-1.875 \\
(1.081)\end{array}$ & $\begin{array}{c}0.125 \\
(1.134) \\
\end{array}$ & $\begin{array}{l}0.670^{* *} \\
(0.223)\end{array}$ \\
\hline $\begin{array}{l}\text { Spomeni Pikettyjeva } \\
\text { imena }(\log )\end{array}$ & $\begin{array}{l}1.403^{* * *} \\
(0.314)\end{array}$ & $\begin{array}{l}1.074^{* *} \\
(0.346) \\
\end{array}$ & \\
\hline Broj citata $(\log )$ & $\begin{array}{l}-0.515^{\star} \\
(0.236)\end{array}$ & $\begin{array}{c}0.220 \\
(0.233)\end{array}$ & $\begin{array}{c}0.026 \\
(0.046)\end{array}$ \\
\hline Kurtoazni citat & $\begin{array}{l}-0.439 \\
(0.926)\end{array}$ & $\begin{array}{l}-1.037 \\
(0.962)\end{array}$ & $\begin{array}{c}-0.598^{* * *} \\
(0.121)\end{array}$ \\
\hline Piketty kao podaci & $\begin{array}{c}0.058 \\
(0.664) \\
\end{array}$ & $\begin{array}{l}-1.138 \\
(0.891) \\
\end{array}$ & $\begin{array}{l}-0.144 \\
(0.117) \\
\end{array}$ \\
\hline $\begin{array}{c}\text { Rad citira "Dohodovnu } \\
\text { nejednakost" }\end{array}$ & $\begin{array}{l}-1.207 \\
(0.672)\end{array}$ & $\begin{array}{l}-2.704^{\star *} \\
(0.794)\end{array}$ & $\begin{array}{l}0.823^{\star * *} \\
(0.149)\end{array}$ \\
\hline Rad citira Kapital & $\begin{array}{l}-1.477 \\
(0.902)\end{array}$ & $\begin{array}{l}2.205^{*} \\
(1.060)\end{array}$ & $\begin{array}{l}0.769^{* * *} \\
(0.196)\end{array}$ \\
\hline Konstanta & $\begin{array}{c}-3.622^{\star *} \\
(1.219) \\
\end{array}$ & $\begin{array}{c}-6.243^{\star * *} \\
(1.507) \\
\end{array}$ & $\begin{array}{l}0.912^{\star *} \\
(0.265)\end{array}$ \\
\hline Broj observacija & 255 & 255 & 255 \\
\hline (Pseudo) R na kvadrat & 0.478 & 0.631 & 0.661 \\
\hline
\end{tabular}

Napomena: Koeficijenti i standardne pogreške u zagradama. Statistička značajnost: ${ }^{*} \mathrm{p}<0.05$; ${ }^{* *} \mathrm{p}<0.01 ;{ }^{* *} \mathrm{p}<0.001$. 
dela. Prvi model istražuje determinante pozitivne evaluacije Pikettyjeva rada, a drugi model istražuje determinante negativne evaluacije Pikettyjeva rada. Pozitivno je čitanje Pikettyja bilo vjerojatnije $\mathrm{u}$ onim radovima koji su prikupljeni $\mathrm{u}$ sociološkoj bazi SocINDEX, a negativno čitanje u onim radovima koji su prikupljeni u ekonomskoj bazi EconLit. Ovo korespondira s deskriptivnom analizom koja je predstavljena u Tablici 1. I sociologija i ekonomija su dale i kritike i pohvale, ali ravnoteža je u slučaju sociologije nagnuta Pikettyju u prilog, dok u ekonomiji nije. Opet valja ponoviti da nalaze vezane uz sociološku bazu SocIN$D E X$ treba interpretirati s ogradom jer broj radova prikupljen u toj bazi nije velik.

Osim toga, čini se da je vjerojatnost da radovi daju negativnu i pozitivnu evaluaciju Pikettyja viša kod radova koji više spominju Pikettyjevo ime. Drugim riječima, detaljnije rasprave o Pikettyju sklonije su uravnoteženijem prikazivanju njegova rada. Koeficijent koji prati učestalost spominjanja njegova imena je pozitivan i statistički značajan u prvom i drugom modelu, a isti je nalaz repliciran u trećem modelu. Dakle, što detaljnije netko čita Pikettyja, tim je veća vjerojatnost da će biti teže dati jednostrano mišljenje o njegovom radu. Na primjer, David Soskice (2014: 651, 652), koji u svom radu Pikettyja spominje oko 100 puta, piše da je Kapital "jedna od najsnažnijih knjiga koju sam pročitao u dugo vremena, lucidno napisana, lako čitljiva i izvanredno interesantna", ali istovremeno dodaje da Pikettyjev "jednostavni model, premda jasan i oštrouman, skoro potpuno ignorira interakcije između politike, povijesti i tehnoloških promjena.” Drugim riječima, što se više čita Pikettyja to se više vidi i dobro i loše u njegovom radu.

\section{Ekonomska kritika}

Pikettyjeva teorijska osnova jest relativno jednostavna i uglavnom se temelji na neoklasičnoj ekonomiji. Njegov je pristup maksimalno induktivan te Kapital zapravno niti nema teorijske temelje u uobičajenom smislu. Pikettyjevi nalazi zapravo su računovodstvene prirode. Zbog toga se ekonomska kritika usmjerila na način na koji je definirao i mjerio svoje glavne veličine.

Prvo je pitanje da li se kapital može mjeriti. Ovdje se pojavljuju duhovi tzv. "kejmbridžske kontroverze o kapitalu" (za uvod vidi Burmeister, 2000; Cohen i Harcourt, 2003). Rasprava je dobila ime po tome što su se obje stane nalazile u Cambridgeu: neoklasični ekonomisti (Paul Samuelson i Robert Solow) na MIT-u u Cambridgeu u Massachusettsu, a heterodoksni ekonomisti (Joan Robinson i Piero Sraffa) u engleskom Cambridgeu. Problem se može sažeti ovako: da bismo utvrdili kamatu, moramo znati kolika je granična korisnost kapitala, koja je pak određena količinom kapitala, a ona je pak određena distribucijom dohotka koja određuje kamatu. Prema tome, heterodoksna je kritika neoklasični pristup optužila da je cirkularan.

Glavna teza engleskog Cambridgea izložena je u Sraffinoj knjizi čiji naslov Proizvodnja roba pomoću roba - sumira glavni heterodoksni zaključak kejmbridžske kontroverze o kapitalu (Sraffa, 1980). Naime, svaki je stroj ujedno i roba, tj. proizvod nekih drugih kapitalnih dobara i tako unedogled. Ovaj zaključak također proizlazi iz analize prve knjige Marxovog Kapitala (Strpić 2010: 60-62, 67-69). Za potpuno bi vjerodostojan izračun profitne stope bilo potrebno endogenizirati čitav niz varijabli koje neoklasična ekonomija obično tretira kao zadane. Drugim riječima, pitanje je da li 
se može govoriti o kapitalu izvan konteksta, pa i političkog i institucionalnog konteksta. Iako je Samuelson u ime američkog Cambridgea priznao poraz (Samuelson, 1966), većina je neoklasične škole nastavila s radom kao da je kapital lako definirati i mjeriti (Syll, 2014: 40-41).

Piketty sumarno proglašava pobjedu američkog Cambridgea (Piketty, 2014: 261) jer mu to omogućuje da nastavi s empirijskim poslom. Međutim, ovakav beskrupulozni empiricizam ima svoju cijenu: Piketty otvara prostor kritici da su mu glavne teze u osnovi tautološke. S druge strane, pitanje je da li se iz ovog problema uopće može izaći a da se ne gradi nova teorijska osnova koja će zamijeniti neoklasičnu ortodoksiju. U taj se posao Piketty nije upuštao, a eventualne alternative, poput Keynesove i Kaleckijeve, nije uzimao u obzir. Razlog je vjerojatno u tome što predviđanja takvih modela mogu voditi u različita, često i suprotstavljena ravnotežna stanja (Varoufakis, 2014: 29-30; Patnaik, 2014: 58$59,61-62)$. Odnos $r>g$ daje jednostavno predviđanje dugoročne ravnoteže. Ali takvo predviđanje postaje moguće tek uz prihvaćanje nekih osnova neoklasične ortodoksije.

Neoliberalna ortodoksija relevantna je za još jedan teorijski temelj u Kapitalu, zapravo za njegov najvažniji element. Naime, riječ je o pitanju povrata na kapital i njegovom odnosu spram povrata na rad. Pitanje koje se ovdje postavlja jest koliko je elastična supstitucija kapitala za rad. Neoklasična polazišna točka je svijet pune zaposlenosti faktora proizvodnje (rada, kapitala i u suvremenim privredama relativno nevažne zemlje), tj. svijet u kojem je povrat na svaki od faktora proizvodnje određen marginalnom produktivnošću danog inputa. Kada elastičnost supstitucije iznosi 1, kapi- tal i rad su podjednako produktivni tj. povrat na rad i kapital su isti. Kada je elastičnost veća od 1, kapital je produktivniji, tj. povrat na kapital je veći od povrata na rad. Kada je elastičnost manja od 1, rad je produktivniji, tj. povrat na rad je veći od povrata na kapital.

Dugo se smatralo da je povrat radu i kapitalu podjednak. Ova se stilizirana činjenica temeljila na istraživanjima provedenim u SAD pedesetih godina $\mathrm{i}$ odraz je ekonomskog optimizma tog vremena. Prema Pikettyjevom izračunu, elastičnost supstitucije iznosi između 1.3 i 1.6 (Piketty, 2014: 250). Međutim, ta je procjena kontraverzna, a Pikettyjevi kritičari navode druge studije prema kojima je elastičnost supstitucije manja od 1 (Rognlie, 2014: 7; Rowthorn, 2014: 12831284). Ovo je pitanje važno jer elastičnost čak i malo veća od 1 može na dugi rok dovesti do stvaranja velikih dinastijskih bogatstava i do patrimonijalnog kapitalizma o kojem govori Piketty.

Treba reći da se Pikettyjev izračun dosta razlikuje od izračuna drugih ekonomista jer se temelji na mnogo dužem razdoblju i na mnogo većem broju zemalja. U ostalim se studijama obično razmatraju samo američki podaci, samo za nekoliko industrijskih sektora te samo za nekoliko godina. Također, Pikettyjeva definicija kapitala uključuje bogastvo, dok se uža ekonomska definicija temelji samo na kapitalu koji se izravno koristi u proizvodnji. Prema tome, riječ je zapravo o neusporedivim konceptima. Piketty tumači veću elastičnost time da se u današnjem kontekstu kapital može koristiti na veći broj načina. Nekada je bogatstvo uglavnom bilo zemlja, pa su - kao u romanima Jane Austen - bogataši bili oni s mnogo zemlje. Današnje je vrijeme drugačije jer je suvremeni kapital, za razliku od nekadašnjih velikih zemljoposjedničkih imanja, svestran i fleksibilan. Zato 
marginalna produktivnost može biti viša, a povrat na kapital veći.

Time se stiže do sljedećeg važnog elementa u Kapitalu. Naime, postavlja se pitanje da li će gore opisani scenarij koji dovodi do akumulacije kapitala i gomilanja velikih bogatstava - nužno prouzročiti korekciju u obliku opadajuće profitne stope. Ovo je neoklasični odgovor na eventualno gomilanje bogatstva (Rognlie, 2014; Rowthorn, 2014; Semeniuk, 2014; Soskice, 2014). Piketty se slaže da će profitna stopa pasti, ali navodi da će pad biti manji nego što bi trebao biti da se spriječi gomilanje bogatstva $u$ razmjerima koji bi posramili i rentijerske zemljopsjednike iz romana Jane $\mathrm{Au}$ sten. Opadajući prinosi su mali upravo zbog visoke elastičnosti supstitucije kapitala radom. Ako je elastičnost supstitucije između 1.3 i 1.6, taj će pad biti toliko blag da se može govoriti o manje-više stabilnim profitnim stopama (Piketty i Zucman, 2014: 1304; Piketty, 2014: 400-406). Prema tome, ako očekujemo da stope ekonomskog rasta padnu, kao što se dogodilo u bogatim zapadnim demokracijama nakon kraja poslijeratnog buma, te ako očekujemo da je povrat na kapital stabilan, onda odnos $r>g$ zaista postaje relevantan u stvaranju dosad neviđene akumulacije bogatstva.

Kao što se može vidjeti, Pikettyevi zaključci ovise o nekoliko početnih pretpostavki koje nisu prihvatljive svim ekonomistima: da je kapital bogatstvo, da ga se može mjeriti i da je elastičnost supstitucije relativno visoka. Podacima se nema mnogo što za prigovoriti pa se većina kritika usmjerila na definiranje prvih veličina. Male promjene u definicijama mogu imati značajne posljedice po njegova predviđanja. Na primjer, izbacivanje nekretnina iz definicije kapitala uvelike bi izmijenilo Pikettyjeve zaključke. Porast nejednakosti u zadnjih nekoli- ko desetljeća blisko je povezan s rastom tržišne vrijednosti nekretnina (Rognlie, 2014: 16-18; Rowthorn, 2014: 1283). Za marksističke je ekonomiste, pak, uklanjanje nekretnina iz definicije kapitala važno jer se onda pokazuje da je u istom razdoblju profitna stopa pala, kao što pretpostavlja marksistička teza o tendenciji pada profitne stope (Roberts, 2014).

Ovo je sve cijena Pikettyjeve odluke da preskoči gradnju teorije te da pomoću pragmatičnog prilagođavanja nekih elemenata neoklasične ekonomije pokuša empirijskom poslu dati tek nužni minimum teorijske podloge. $\mathrm{K}$ tome, korištenje neoklasične ekonomije ima korisnu nuspojavu da autora čini respektabilnim u mainstreamu te discipline, ali i šire javnosti, dok bi ga prihvaćanje neke heterodoksne ili kritičke perspektive vjerojatno pretvorilo u autsajdera.

\section{Sociološka kritika}

Kako sociologija gleda na Pikettyjev rad? Tipovi kritika razlikuju se od kritika koje dolaze od ekonomista. Pri tome valja spomenuti da nešto lijevija orijentacija sociologije kao cjeline - barem u usporedbi s ekonomijom - pretvara Pikettyja u političkog saveznika za velik broj sociologa. Međutim, njegova politička pozicija sama po sebi ne dovodi nužno niti do analitičkih pohvala niti do kritika. Za to je ipak potrebno razmotriti kako sociolozi komentiraju njegov rad te što bi voljeli u njemu promijeniti.

U sažetom se obliku većinu tipičnih socioloških reakcija može pronaći u posebnom broju British Journal of Sociology posvećenom Kapitalu (svezak 65, broj 4, godina 2014). Ovaj broj sadrži deset tekstova koji komentiraju Pikettyjevu knjigu iz različitih perspektiva. 
Ondje se može naći popis svih refleksnih reakcija sociologa: primjerice, da Piketty nedovoljno raspravlja pitanje roda (Perrons, 2014) ili pitanje geografske lokacije kapitala (Jones, 2014). Ovaj tip kritike je pomalo šablonski: pronalazi se neka varijabla koja potencijalno ima ulogu u stvarnom svijetu kompleksne nejednakosti te se ustanovljuje da ju Piketty nije uključio u svoju (nužno) redukcionistič$\mathrm{ku}$ analizu.

Međutim, možda je najčešća sociološka kritika usmjerena na njegovo shvaćanje klasa (Savage, 2014: 600; Harvey, 2015: 17; Lotz, 2015: 375; Wright, 2015: 61). U skladu sa svojim podacima, Piketty klase definira prema položaju u distribuciji bogatstva (Piketty, 2014: 278281): najbogatijih 10 posto (viša klasa), idućih 40 (srednja klasa) i donjih 50 posto (niža klasa). Nema pokušaja da se klase povežu sa zanimanjima koja pojedinci obnašaju ili sa strukama za koja su obrazovani. Također nema niti pokušaja da se klase promatraju relacijski, kao što se čini u marksističkoj tradiciji klasne analize (Wright, 2015: 61). S time je povezana i kritika da kapital nije "stvar" kako ga definira Piketty - već proces i odnos koji definira čitavo društvo (Lotz, 2015: 375-376; Harvey, 2015: 17). Naravno, teško je zamisliti kako bi itko mogao sakupiti podatke za više stoljeća i za barem tri do četiri zemlje, kao što čini Piketty, ukoliko bi usvojio takvu definiciju kapitala. Kod Pikettyja, klasni karakter kapitalizma nije definiran eksploatacijom nego akumulacijom.

S druge strane, Kapital dijeli neke neočekivane sličnosti s radom Pierrea Bourdieua, čija je inačica klasne analize postala vrlo popularna posljednjih desetak godina. Prema tome, iako ga njegova definicija klasa udaljava od marksističke sociologije, Kapital otvara prostor za sinergiju s onim sociološkim analitičarima koji se vode idejama Bourdieua. Na- ime, Pikettyjev fokus na nasljeđeno bogatstvo podudara se s Bourdieuovom analizom kulturnog kapitala i distinkcijama u ukusima koje više klase stvaraju kako bi se odvojile od nižih (Savage, 2014: 601). Naglasak se ne stavlja toliko na antagonizam koji je utemeljen u svijetu proizvodnih odnosa - kao što se čini u marksističkoj klasnoj analizi - već na različite stilove života i različite društvene svjetove pripadnika različitih klasa. Pikettyjevo citiranje romana Jane Austen i Honoréa de Balzaca tu ima ulogu koju bi inače imala sociološka etnografija. Opis svijeta bogatih koji se prenosi iz tih romana služi tome da se suhi ekonomski podaci učine življima. Za sociologe Pikettyjev poziv da više istražujemo najbogatije rezonira s dobro ukorijenjenom kritikom da je sociologija prečesto istraživala "prema dolje" (tj. siromašnije ljude i radničku klasu), a premalo "prema gore” (tj. najbogatiju elitu). Prostor za etnografije koje se bave najbogatijim 1 posto ili najbogatijim 0.1 posto je velik, a neki sociolozi su već započeli ovaj posao (dobar primjer je Khan, 2010).

U posebnom broju British Journal of Sociology i drugdje, sociolozi često iznose primjedbu da Piketty ima nedostatnu teorijsku artikulaciju političkog djelovanja i društvenih pokreta. Ovo je možda najozbiljnija primjedba koju sociolozi upućuju Pikettyju, a koja se rijetko čuje od ekonomista. Iako Piketty traži političko-ekonomsku analizu, on ostaje isključivo na terenu ekonomskih podataka. I premda mnogo spominje političke potrese srednjeg dijela dvadesetog stoljeća (Piketty, 2014: 52, 166, 348-351, 578), njegova analiza ne teoretizira na sustavan način tipove političke i društvene intervencije koji su se dogodili između dva svjetska rata te neposredno nakon njih (Milkman, 2014: 377; Buroway, 2015: 12; Harvey, 2015: 17). A upravo su 
to procesi koji su uspjeli preokrenuti inače "prirodnu" sklonost kapitalizma da generira visoke profitne stope koje dovode do porasta nejednakosti. Zato nekoliko sociologa spominje Veliku preobrazbu Karla Polanyija (1999 [1944]) kako bi ponudili primjere analize koja teoretizira kontradjelovanje društva kojim se ono brani od čiste tržišne logike (Buroway, 2015; Milkman, 2014: 377). Za Burowaya, Polanyi nudi puno bolju osnovu za teoretiziranje ritmova kapitalizma od jednostavnog mjerenja ekonomske nejednakosti (Buroway, 2015: 25).

Ova je kritika tim važnija s obzirom na to da Piketty predlaže globalni progresivni porez na bogatstvo kao svoju glavnu preporuku. Naime, u Kapitalu se ne skicira put kojim bi se do takve regulacije došlo. Nejasno ostaje koji bi se to politički akteri mogli izboriti za novi globalni porez. I sam Piketty se slaže da je njegov prijedlog utopijski (Piketty, 2014: 602). Premda nije loše da društveni znanstvenici nude utopije ipak bi bilo poželjno da se uz sam cilj raspravi i način na koji bismo do tog cilja mogli doći. Za usporedbu može poslužiti mnogo skromniji Tobinov porez koji predviđa da se na globalnoj razini financijske transakcije oporezuju stopom od pola posto. Ovaj je prijedlog predložen još ranih sedamdesetih, a unatoč svojoj skromnosti dosad nije uspio zaživjeti. U usporedbi s Tobinovim porezom, Pikettyjev prijedlog je mnogo radikalniji. S druge strane, teško je zamisliti da bi se društveni pokreti mogli inspirirati Pikettyjevom tehnokratskom idejom, a upravo su društveni pokreti ti koji bi eventualno mogli učiniti da Pikettyjev globalni porez postane realnost. Pikettyjeva rasprava njegovih policy preporuka odiše tehnokratskim duhom koji je u skladu s njegovom umjerenom i konvencionalnom socijaldemokratskom orijentacijom.
Kritika da kod Pikettyja nedostaje analiza političkog djelovanja i društvenih pokreta na određeni način rezonira s ekonomskom kritikom koja kreće od kejmbridžske kontroverze o kapitalu. Iako su izrečene drugačijim jezicima, u osnovi je riječ o sličnim primjedbama: Piketty o političkim i institucionalnim pitanjima govori na ad hoc način. Primjerice, Piketty i Saez (2003: 34) porast nejednakosti koji se na posebno oštar način dogodio u Sjedinjenim Državama dijelom objašnjavaju kao posljedicu društvenih normi koje postoje na tržštu rada, a koje određuju pravila za nagrađivanje najbogatijih 1 posto. Postavlja se pitanje: otkuda dolaze te društvene norme? Piketty priznaje da je pitanje relevantno, ali ne nudi odgovor. Umjesto toga prebacuje odgovornost na druge društvene znanosti, kao što su sociologija, psihologija, kulturna i politička povijest (Piketty, 2014: 379). Premda je lijepo čuti od nekog ekonomista da su druge društvene i humanističke znanosti važne, njegovo otklanjanje ovog problema u koliziji je s proklamiranim ciljem izgradnje političke ekonomije kao interdisciplinarnog područja (Piketty, 2014: 679; Perrons, 2014: 673). Naravno da je ovako nešto vrlo teško napraviti, ali bez razmatranja političkog aspekta porasta nejednakosti Piketty ne može objasniti zašto je porast nejednakosti bio oštriji u anglosaksonskim zemljama nego u kontinentalnim europskim zemljama. Premda je odnos $r>g$ predstavljen kao univerzalan, čini se da se različito materijalizira u različitim političkim i institucionalnim kontekstima.

\section{Što dalje?}

Ova je rasprava tipičnih ekonomskih i socioloških kritika dala pregled postojećih diskusija o Pikettyju. Treba napo- 
menuti da neke od tih kritika - kako ekonomskih tako i socioloških - ne nude praktične niti izvedive prijedloge. Primjerice, primjedbe na njegovu definiciju kapitala, bilo da dolaze iz ekonomskih krugova bilo iz marksističke klasne analize, tražile bi od Pikettyja da napiše sasvim novu knjigu. Neke se druge dvojbe, poput one o tome koliko zaista iznosi elastičnost supstitucije kapitala radom, niti ne mogu razriješiti bez usporedivih podataka podjednake kvalitete. Prema tome, kritika Pikettyja oscilira između traženja radikalno drugačijih teorijskih temelja i traženja alternativne usporedive empirije. Za prvi posao Piketty nije imao ambicije, a za drugi nitko još nije pokazao revnost u skupljanju podataka koja bi sličila Pikettyjevoj.

Kako bi se moglo otići korak dalje, i u znanstvenom i u reformskom smislu? Ovdje ću skicirati tri mogućnosti. Prvo se pitanje tiče važnosti teme, tj. zašto je nejednakost uopće važna tema. Naime, Piketty na ovu dilemu ne daje eksplicitan odgovor, a sustavnijim bi se bavljenjem ovim pitanjem moglo značajno unaprijediti raspravu o nejednakosti. Drugo se pitanje tiče već spomenute ateorijske prirode Pikettyjevog pothvata tj. činjenice da bi istraživanje nejednakosti moglo profitirati ukoliko bi se Pikettyjeva revnost u prikupljanju podataka kombinirala sa sličnom predanošću teoriji. Treće je pitanje bi li umjesto Pikettyjevih policy preporuka bilo svrishodnije razmišljati o nekim drugim pristupima problemu nejednakosti. Naime, kod Pikettyjevog se prijedloga globalnog progresivnog poreza pojavljuju pitanja ne samo pitanja političke izvedivosti već i ekonomske efikasnosti.

Prva se kritika tiče legitimacije problema nejednakosti. Zašto bi to uopće bila važna tema? Za većinu neoklasične ortodoksije distribucija bogatstva nije nužno problematična za uredno funkcioniranje privrede. Prije Pikettyja se problem nejednakosti obično postavljao kao odabir između jednakosti i efikasnosti. Ovakav je pristup populariziran knjigom kejnzijanca Arthura Okuna (1975), a prihvaćali su ga i autori izvan ekonomske znanosti. Primjerice, Pontusson (2005) postavlja problem na sličan način: prosperitet dolazi ako prihvatimo više nejednakosti, a društvo s više jednakosti dolazi uz cijenu nižeg općeg standarda. Pikettyjevo je postavljanje problema sasvim oprečno i potencijalno mnogo izazovnije.

Piketty ne daje mnogo prostora raspravi o tome zašto bi nejednakost bila važna tema. On ili misli da će čitatelji dijeliti njegov umjereni lijevi svjetonazor ili pak smatra da je teza o tome kako rentijersko društvo potkopava meritokratske temelje kapitalizma dovoljan razlog za to. Međutim, moralni i politički argumenti najvjerojatnije neće uvjeriti skeptike, a sam Piketty ne daje mnogo podataka o tome je li povećana nejednakost umanjila efikasnost zapadnih kapitalističkih zemalja. Prema tome, korak kojeg Piketty ne poduzima, a trebalo bi ga poduzeti, jest ispitati jesu li društva s više jednakosti ujedno i ekonomski efikasnija. Ekonomski argument u prilog jednakosti imao bi mnogo više odjeka kod onih kojima politički i moralni argumenti nisu uvjerljivi. Nekoliko je autora počelo zagovarati upravo ovakvu tezu (Wilkinson i Pickett, 2010; Stiglitz, 2012; Dorling, 2014), a najsustavnije empirijske testove napravio je MMF, institucija od koje bi se takvo što najmanje očekivalo (Ostry, Berg i Tsangarides, 2014). Prema ovoj komparativnoj analizi, niža nejednakost korelirana je s bržim i trajnijim ekonomskim rastom, dok se redistributivne politike pokazuju kao relativno benigne u svom učinku na rast. 
Prema tome, čini se da veliki i teški Okunov odabir između jednakosti i efikasnosti niti ne postoji. Akumulacija empirijskih nalaza ove vrste predstavljala bi korak naprijed u odnosu na Pikettyjev rad jer bi se osim ilustrativnih primjera iz beletristike ponudilo i tvrde podatke. Pikettyju možemo zahvaliti što je sada moguće raspravljati o nejednakosti a da se tema nužno ne postavlja u okvir Okunove dileme.

Druga kritika tiče se Pikettyjeve siromašne teorijske podloge. Pritom valja napomenuti da njegov beskrupulozno deskriptivni stav ima određene prednosti. Na taj je način došao do šire publike koja ne bi imala strpljenja za dugu teorijsku raspravu. Piketty je mogao odmah uskočiti u podatke i na vizualno atraktivan i metodološki pristupačan način predočiti čitateljima dugoročne trendove. Premda je Kapital dosta tehnička knjiga, ona nigdje ne zahtijeva niti teorijsko niti statističko predznanje. Ali cijena tog odabira jest teorijska oskudnost knjige. Međutim, postoje teorijske perspektive koje bi bile kompatibilne s Pikettyjevim podacima, a koje u svojim aplikacijama nipošto nisu odvojene od empirije. To se prije svega odnosi na literaturu o dugim valovima (Kondratievovi ciklusi) i stoljetnim trendovima.

Prvi su popularizirani kroz rad ruskog ekonomista Kondratieva te kasnije kod marksističkih autora poput Mandela (Kondratiev, 1979; Mandel, 1981), dok su drugi popularizirani kod povjesničara poput Braudela i drugih (Braudel, 1992; Fischer, 1996; Arrighi, 2007). Pikettyjevo makrohistorijsko računovodstvo bilo bi vrlo kompatibilno s takvim pristupom, pogotovo s francuskom Annales školom. I premda Piketty kratko spominje Braudela kao znanstveni uzor (Piketty, 2014: 43), on nigdje ne koristi njegov rad. Ova bi literatura Pikettyjevom pothvatu mogla odgovarati i više od neoklasične ekonomije s kojom povremeno pragmatično paktira kako bi mogao što prije preći na empirijski dio posla. Možda je za Pikettyja predstavljalo problem što je ova literatura često - premda ne i isključivo - marksistički intonirana. Potencijalno je najzanimljivija literatura o stoljetnom trendu s obzirom na to da su povjesničari koji su se njime bavili otkrili da u svojim raziličitim fazama korespondira s različitim trendovima $\mathrm{u}$ kretanju nejednakosti (Fischer, 1996: 236-241). Osim toga, ova literatura dolazi s nizom teorijskih teza o tome što pokreće takve dugoročne ritmove. Drugim riječima, ta bi literatura mogla Pikettyju biti relevantan sugovornik - potencijalno relevantniji of Marxa i Kuznetsa - ali on se na nju nije referirao.

I najzad, treća se kritika tiče Pikettyjevih policy preporuka. Kao što je već spomenuto, Piketty ima slijepu točku za političke aktere i društvene pokrete. Da bi se njegov globalni porez uveo, potrebna bi bila rijetko viđena razina društvene mobilizacije. Bez skice kako da se pokrene takva mobilizacija, Pikettyjevi prijedlozi ostaju na razini tehnokratskog uvjeravanja i lobiranja elita. Međutim, pitanje je bi li pojačano progresivno oporezivanje uopće bilo efikasno u neutraliziranju tendencije $r>g$. Tek bi mnogo više konfiskatorne porezne stope, kakve su postojale sredinom dvadesetog stoljeća, mogle eliminirati najveća rentijerska bogatstva. Piketty pozitivno piše o konfiskatornim poreznim stopama, ali se u Kapitalu ne odvažuje preporučiti slične mjere.

Kako onda do manje nejednakosti? Jedna mogućnost jest poduprijeti aktere koji se već bore protiv nejednakosti. To bi značilo poduprijeti sindikate gdje postoje, zagovarati njihovo osnivanje gdje ne postoje i podržavati kampanje za 
povišenje minimalne plaće (Galbraith, 2014: 82). Druga bi mogućnost bila ostati unutar tehnokratskog pristupa, bez mobilizacije odozdo. Jedna takva politika jest financijska represija, tj. skup mjera kojima bi se stopa povrata na kapital umjetno smanjila ispod razine inflacije. Ovo se može postići određivanjem maksimalnih kamatnih stopa, visokih bankarskih rezervi, obavezom banaka da drže državne obveznice i kapitalnim kontrolama. Na taj bi se način, uz smanjenje rentijerskog povrata na kapital, moglo smanjiti i javni dug. Sama je mjera složena i netransparentna (za uvod vidi Reinhart i Sbranica, 2015), ali je lakše izvediva od globalnog progresivnog poreza.

Treća je mogućnost ozbiljnije razmišljati o novim društvenim utopijama, nešto čemu Piketty nije previše sklon. Ideja koja je do sada privukla najviše pažnje jest temeljni dohodak (basic inco$m e)$. Riječ je o mjesečnom iznosu koji bi se bezuvjetno plaćao svim građanima neke zemlje i koji bi svakome omogućio pristojan životni standard. Kao nova forma socijalnog osiguranja, temeljni bi dohodak mogao zamijeniti neke postojeće programe države blagostanja, pogotovo one koji se provode s mnogo uvjeta i birokracije. Ovu mjeru zagovaraju razne ideološke struje, ali najčešće se promiče na ljevici (Standing, 2011: poglavlje 7; Mason, 2015: poglavlje 10; Srnicek i Williams, 2015: poglavlje 6). Slična su mjera tzv. potpore za dionike (stakeholder grants) (Ackerman, Alstott i Van Parijs, 2006). Njima bi svaka punoljetna osoba dobila jednokratnu poveću sumu kojom bi se mogla uključiti u kapitalizam na način na koji ona to odluči, bilo da postane poduzetnik ili kupuje portfelj dionica na burzi. Ovakve mjere nam omogućuju da zamišljamo nove egalitarne forme kapitalizma. Istovremeno, one daju odgovor na jedno pitanje koje je kod Pikettyja ostalo visjeti u zraku. Naime, iako zagovara globalno progresivno oporezivanje, Piketty ne kaže što bi učinio s prikupljenim novcem. Za njega je oporezivanje korisno ponajprije jer se kroz smanjenje najvećih bogatstava regulira kapitalizam. Ovdje spomenute mjere nude i konkretni sadržaj - cilj koji bi mogao inspirirati društvene pokrete na mobilizaciju. $^{3}$

\section{Zaključne napomene}

U ovom se radu prikazala postojeća literatura o Pikettyju, s posebnim naglaskom na prihvaćanje njegova rada u društvenim znanostima. Kao što se moglo vidjeti kroz analizu radova koji citiraju Pikettyja, recepcija uglavnom balansira između pozitivnog i negativnog, s time da kod sociologije preteže na pozitivnu stranu, a kod ekonomije na negativnu. Tipovi kritika koje ekonomisti i sociolozi upućuju Pikettyju su različiti. Ekonomisti češće osporavaju način na koji je definirao početne veličine te dovode u pitanje neke njegove mjere. Sociolozi pak prigovoraju Pikettyju na tome kako je definirao klase te kako ne teoretizira društvene pokrete.

Pikettyjevom se Kapitalu ne može poreći zasluga za populariziranje teme nejednakosti, koliko god da je ujedno bila riječ o potražnji javnosti. Rasprave o nejednakosti više neće moći zaobići način na koji je Piketty postavio problem. Kao što je rečeno, ovaj je okvir potencijalno mnogo produktivniji od postojećeg koji nam sugerira nužni odabir iz-

3 Piketty se izjasnio protiv temeljnog dohotka, iako je za sličnu ali konzervativniju verziju negativnog oporezivanja dohotka. Vidi: http://www.basicincome.org/news/2015/09/ thomas-piketty-discusses-book-basic-income/ Pristupljeno 4. travnja 2016. 
među jednakosti i efikasnosti. Međutim, Pikettyjeva znanstvena i politička agenda nije bez mana. Najprije, Piketty nam ne daje uvjerljive razloge zašto bi nejednakost uopće bila važna tema. Ta se tema može dodatno etablirati ako se akumulira znanje o potencijalnoj sinergiji jednakosti i efikasnosti. Drugo, $\mathrm{Ka}$ pital je teorijski oskudna knjiga. Premda je ova odluka vjerojatno pomogla da se knjiga proda u više primjeraka, ona nije bez svoje cijene. Kapital ne nudi temelje za novu političku ekonomiju, a ignorira mnoge radove koji bi mu mogli biti od koristi, pogotovo one koji se bave načinom na koji kapitalizam funkcionira na dugi rok. I treće, njegova glavna policy preporuka - globalno progresivno oporezivanje - je istovremeno politički nerealna i tehnički nedovoljno efikasna. Bit će potrebno zamišljati alternative na ambiciozniji način, ako se želi izaći iz situacije koju Piketty uspješno i efektno opisuje svojim podacima.

\section{LITERATURA}

Ackerman, Bruce, Anne Alstott i Philipee Van Parijs (ur) (2006) Redesigning Distribution: Basic Income and Stakeholder Grants as Cornerstones for an Egalitarian Capitalism. London: Verso.

Arrighi, Giovanni (2007) Adam Smith in Beijing: Lineages of the Twenty-First Century. London i New York: Verso.

Braudel, Fernand (1992) Materijalna civilizacija, ekonomija i kapitalizam od XV. do XVIII. stoljeća - Vrijeme svijeta. Zagreb: August Cesarec.

Burmeister, Edwin (2000) The Capital Controversy. U: Heinz Dieter Kurz (ur) Critical Essays on Piero Sraffa's Legacy in Economics. (str. 305-14). New York: Cambridge University Press.

Buroway, Michael (2015) Facing an Unequal World. Current Sociology 63(1): 5-34.

Cohen, Avi J. i G. C. Harcourt (2003) Retrospectives: Whatever Happened to the Cambridge Capital Controveries? Journal of Economic Perspectives 17(1): 199-214.

Dorling, Daniel (2014) Inequality and the 1 Percent. London i New York: Verso.
Fischer, David Hackett (1996) The Great Wave: Price Revolutions and the Rhythm of History. New York: Oxford University Press.

Galbraith, James K. (2014) Kapital for the Twenty-First Century? Dissent 61(2): 77-82.

Harvey, David (2015) Afterthoughts on Piketty's Capital. Green Social Thought 66: 16-18.

Jones, Gareth A (2014) Where's the Capital? A Geographical Essay. British Journal of Sociology 65(4): 721-35.

Khan, Shamus (2010) Privilege: The Making of and Adolescent Elite at St. Paul's School. Princeton: Princeton University Press.

Kondratiev, Nikolai (1979) The Long Waves in Economic Life. Review (Fernand Braudel Center) 2(4): 519-62.

Lotz, Christian (2015) Is Capital a Thing? Remarks on Piketty's Concept of Capital. Critial Sociology 41(2): 375-83.

Mandel, Ernest (1981) Kasni kapitalizam: Pokušaj marksističkog objašnjenja. Zagreb: Centar za kulturnu djelatnost SSO. 
Mankiw, Gregory N. (2013) Defending the One Percent. Journal of Economic Perspectives 27(3): 21-34.

Mankiw, Gregory N. (2015) "Yes, r>g. So what?" American Economic Review 105(5): 43-47.

Mason, Paul (2015) PostCapitalism: A Guide to Our Future. Allen Lane: London.

McCloskey, Deirdre Nansen (2014) Measured, Unmeasured, Mismeasured, and Unjustified Pessimism: A Review Essay of Thomas Piketty's Capital in the Twenty-First Century. Erasmus Journal of Philosophy and Economics 7(2): 73-115.

Milanović, Branko (2014) The Return of 'Patrimonial Capitalism': A Review of Thomas Piketty's Capital in the Twenty-First Century. Journal of Economic Literature 52(2): 519-34.

Milkman, Ruth (2014) Review of Capital in the Twenty-First Century. European Journal of Sociology 55(3): 373-77.

Okun, Arthur M. (1975) Equality and Inefficiency: The Big Tradeoff. Washington DC: Brookings Institution.

Ostry, Jonathan D., Andrew Berg, i Charalambos G. Tsangarides (2014) Redistribution, Inequality, and Growth. IMF Discussion Note: 1-30.

Patnaik, Prabhat (2014) Capitalism, Inequality and Globalization Thomas Piketty's Capital in the Twenty-First Century. International Journal of Political Economy 43(3): 55-69.

Perrons, Diane (2014) Gendering Inequality: A Note on Piketty's Capital in the Twenty-First Century. British Journal of Sociology 65(4): 667-77.

Piketty, Thomas (2014) Kapital u 21. stoljeću. Zagreb: Profil.

Piketty, Thomas i Emmanuel Saez (2003) Income Inequality in the United States,
1913-1998. Quarterly Journal of Economics 118(1): 1-39.

Piketty, Thomas i Gabriel Zucman (2014) Capital is Back: Wealth-Income Ratios in Rich Countries 1700-2010. Quarterly Journal of Economics 129(3): 12551310.

Polanyi, Karl (1999 [1944]) Velika preobrazba: Politički i ekonomski izvori našeg vremena. Zagreb: Jesenski i Turk.

Pontusson, Jonas (2005) Inequality and Prosperity: Social Europe vs. Liberal America. Ithaca NY: Cornell University Press.

Reinhart, Carmen M. i M. Belen Sbranica (2015) The Liquidation of Government Debt. IMF Working Paper: 1-47.

Roberts, Michael (2014) Piketty - in French it's Worse. https://thenextrecession.wordpress.com/2014/04/30/ piketty-in-french-its-worse/ Pristupljeno 4. travnja 2016.

Rognlie, Matthew (2014) A Note on Piketty and Diminishing Returns to Capital. http://www.mit.edu/ mrognlie/piketty_diminishing_returns.pdf Pristupljeno 4. travnja 2016.

Rowthorn, Robert (2014) A Note on Piketty's Capital in the Twenty-First Century. Cambridge Journal of Economics 38(5): 1275-84.

Samuelson, Paul (1966) A Summing Up. Quarterly Journal of Economics 80(4): 568-83.

Savage, Mike (2014) Piketty's Challenge for Sociology. British Journal of Sociology 65(4): 591-606.

Semeniuk, Gregor (2014) Piketty's Elasticity of Substitution: A Critique. Schwartz Center for Economic Policy Analysis Working Papers: 1-23.

Soskice, David (2014) Capital in the 21st Century: A Critique. British Journal of Sociology 65(4): 650-66. 
Sraffa, Piero (1980) Proizvodnja roba pomoću roba: Preludij za kritiku ekonomske teorije. Zagreb: Centar za kulturnu djelatnost SSO.

Srnicek, Nick i Alex Williams (2015) Inventing the Future: Postcapitalism and a World Without Work. London i New York: Verso.

Standing, Guy (2011) The Precariat: The New Dangerous Class. London i New York: Bloomsbury.

Stiglitz, Joseph (2012) The Price of Inequality: How Today's Divided Society Endangers Our Future. New York: W. W. Norton.
Strpić, Dag (2010) Karl Marx i politička ekonomija moderne. Zagreb: Disput.

Syll, Lars Palsson (2014) Piketty and the Limits of Marginal Productivity Theory. Real-World Economics Review (69): 36-43.

Varoufakis, Yanis (2014) Egalitarianism's Latest Foe. Real-World Economics Review (69): 18-35.

Wilkinson, Richard G. i Kate Pickett (2010) The Spirit Level: Why Greater Equality Makes Societies Stronger. New York: Bloomsbury.

Wright, Erik O. (2015) Class and Inequality in Piketty. Contexts 14(1): 58-61.

\title{
Piketty, economics and sociology: The analytical and political agenda on inequality
}

\begin{abstract}
This article considers the work of Thomas Piketty on inequality, with special emphasis on the reception of his ideas in the social sciences. First, a quantitative analysis of the works that cite Piketty's most important publications examines the reception of Piketty in academic debates. Next, the critiques of Piketty from economics and sociology, two often opposed disciplines that have devoted the most attention to discussing Piketty, are considered. This article supplements existing critiques with additional suggestions that are relevant to both the scientific analysis of inequality and the process of imaging various reforms that could cope with the problem of inequality.
\end{abstract}

KEYWORDS Piketty, economics, sociology, inequality 